\title{
ECONOMISTS THAT HAVE CONTRIBUTED TO ECONOMICS POLICIES IN THE WORLD, OTTOMAN STATE AND REPUBLIC OF TURKEY
}

Erol EREN

Beykent University, Istanbul

\begin{abstract}
In this article, we shall briefly look through the economists that have contributed to the economics in the world, Ottoman State and Republic of Turkey, being well-known by their studies in the field. We shall touch upon economic policy and currents established by these intellectual people. Turkish economics were active in developing economic policies and strategies; however, especially as a result of the contributions made by the scientists took shelter in Turkey during the World War II, the resulting movement led to bringing up a generation of economists. And now we see Turkish economists known well in the economic literature of the world, teaching in the prestigious universities and organizations worldwide; and we mention about these intellectual scientists that make studies mostly-read and take place in the economics literature with high impact scores and their range of studies.
\end{abstract}

Key words: economics, economic thoughts and policies, economics in the Ottoman State, Turkish economic policies, Nobel-prized economists, mostly-read Turkish economists

\section{ECONOMISTS THAT HAVE CONTRIBUTED TO THE WORLD ECONOMY IN THE HISTORY AND ESTABLISHED STRATEGIES AND POLICIES}

In this article, firstly we shall deal with and review briefly the scientists and intellectuals that have contributed to the economics in the history and secondly, discuss the status in the Ottoman State and Republic of Turkey, evaluating our intellectuals contributing to the science of economics and, finally, evaluating the latest status in this regard. It worth's noting that religious values always constituted the building blocks of the economics. The reason is that these very values direct the social behaviors and construct an ethical order. Prophets of the monotheistic religions, except for Buddhism, were, therefore, intellectual people who managed to insert economical rudiments in the rules of the religion, thus creating a lifestyle and moral sentiment.

In the Ancient Greek, Socrates, Aristophanes, Xenophon, Platon, Aristotle were philosophers who thought over the economic events, production of goods and services, roles, ways and methods of the people in earning their life and rules of commodity exchange. Before Thomas Gresham, it was mentioned by the Greek philosophers twenty centuries before that the fortune is meaningful only in case it is used as capital, emphasizing that bad money would drives out good money(www.ekodialog.com/ istisatcilar/ilk_caglarda_ekonomi/)

Rome was a land of agriculture; and the Roman philosophers, therefore, unlike the Greek scientists and philosophers, did not concentrate upon the economics. The philosophers, especially Collumelle, Caton and Varron emphasized the agricultural economy, agricultural productivity and efficiency. The Roman emperor Marcus Aurelius issued decrees and took measures to eliminate unfair distribution of income and slavery. The emperor Justinian also issued decrees and took measures to eliminate economic crises(www.e-ekonomist.net/wp-content/dosyalar/)

In the middle ages when Christianity left its mark on the economical thought, Saint Thomas d'Aquinos and Nicole Oresme have reflected the religious values on the economical relations and put forward their comments and thoughts on this matter (tr.wikipedia.org/wiki/orta_cag/ and www.ekodialog.com/iktisatcilar /orta_cagda_ekonomi/) (While Europe was in a completely infertile era in Middle Ages, we see Sheikh Badraldin in the Islamic world who as a pioneer of socialist and utopist thought would subsequently be an inspiration to the utopists. Sheikh Badraldin is a TurkishIslam intellectual with revolutionary economic ideas in the matter of acquisition and use of the goods and services (www.nedir.antoloji.com/seyh.bedrettin/) 
After conquest of Istanbul, marking the end of Middle Ages, we see Mercantilists characterized by their protectionist and liberal economical ideas, and physiocrats that were for natural order. Mercantilists aimed at developing foreign trade and increase valuable mineral stocks in order to reinforce nation state and state capitalism. Mercantilist intellectuals included Jean Bodin, Jean Colbert, Thomas Munn and Cromwell. They were for free and incentive policies to promote foreign trade of the state. And, thus colonialism started in Europe as a result of foreign trade relations.

Mercantilist ideas also gave way to the utopist economists in Europe. Basing on utopist thoughts supporting centralized states with strong control on the economy, Thomas Moore, Thomasso Campenella, Francis Bacon, Aldous Leonard Huxley, George Orwell, Edward Bellamy, William Morris, Eric Frank Russell and Robert A. Heinlein imagined individual and liberal utopia as well as a state order providing it.(Lavoie,1987). As a result of these ideas, the seeds of liberal classical economical doctrine were planted.

Physiocrats, setting up the analytical study method in Social Sciences, put forward that agricultural life was more important than industry and trade, agriculture being a holy production effort for human happiness. Major physiocrats such as Francois Quesnay, Marquis de Mirabeau, Mercier de la Riviere, Etienne de Condillac, Dupont de Nemours and Jages Turgot were intellectuals of noble origins. .(Lavoie, 1987 and Parkin, 2005).

Scientific economic idea and "laissez faire, laissez passer" philosophy was dominant in the economic though and relations. Of course, as known almost by everybody, the founder of this economic philosophy is Adam Smith. Smith was especially affected by liberal policies of wealthy nation state and liberal policies promoting it.(Ulgener, 1962 and Parasiz, 2006)

Criticizing the classical economic thought with his pessimistic ideas, Robert Malthus tried to draw attention to agriculture again, putting forward that rise of population would cause famine and hunger. And according to Ricardo, value of commodity depends on the labor used for its production. Alleging that fluctuations in the commodity prices also depended on increase and reduction in the labor supply, he formulized the labor-value theory, and criticized the idea held Smith, that is, absolute dominance of foreign trade and put forward comparative dominance, discussing that the foreign trade may develop through encouragement by the government.(Phelps, 1990).

Appearance of the first pioneering socialists alleging that capitalism has cruel pressure on the proletariat inspired Karl Marx, founder of the scientific socialism. These socialist forefathers such as Saint Simon, Charles Fourier and Robert Owen were intellectual known by their thoughts and applications for the proletariat. (Phelps, 1990).

Intellectual forefathers of the French idealist socialist current, Jean Charles Sismondi and P.J.Proudhon talked distinction of two social class, namely, bourgeoisie and proletariat, for the first time in the literature, emphasizing that capitalist system triggered economic crises, they being enemy of the workers' freedom. Karl Marx, founder of the scientific socialism, wrote "Capital", significantly benefiting from thoughts of these philosophers as well as from economic approach of Ricardo and from philosophical approach of Hegel. In fact, Marx is against interventionist dias as he alleged that the liberal opinion would destruct itself, leading to establishment of a proletariat state. For this reason, he fiercely criticized the socialist intellectuals such as Saint Simon, Fourier, Owen, Robertus and Frederick Lassal, founder of syndicalism, for they being interventionalists. As we have mentioned above, Marx adopted labor-value theory of Ricordo to his own economic approach. (Parasız, 2010 and 2006).

Protection of national economies against competition from the foreign countries versus the free foreign trade current of the classical economic approach especially became dominant in Germany and Frederich List and Henry Carey concentrated on measures to protect fresh industries basing on their ideas in this matter.

Marginalist currents, in contrary to the classical and socialist economists, have stated that demand and consumption would be determined by the resulting benefit, value of a commodity or service would depend on the marginal benefit it will bring to their users and, therefore, are variable from one man to another. (http://www.gulsunyay.com). This opinion has set a foundation for thoughts and growth theories in the matter of consumption and saving trends in economy. Leon Walras, Stanley Jevons, Carl Menger and Alfred Marshall were the economists studying on this matter. Stating the interest theory, that the money has its revenue and monetary and interest instruments play important role in the crises 
and conjectural fluctuations, Knut Wicksell has also lead to the general equilibrium and full employment approach of Keynes. (Phelps, 1990, Dornbush and at all,1990).

Modern economics started with the book "General Theory of Employment, Interest and Money" published by J.M.Keynes, the British intellectual economist, in 1936. Keynes has found out deficiencies and misinterpretations of the classical economics as well as its failure in providing general economic equilibrium, and put forward that it is a must for the government to intervene with the economy in order to recover from the economic crisis, eliminate idle capacity and find remedy for unemployment, pointing out important duties of the government in this respect. (Parkin, 2005;Gordon and Ulgener, 1962).

Roy Harrod, Nicholas Kaldor, Abba Lerer, John Hicks, Richard Googwin, Micheal Kalecki, George L.Shackle, Luigi Pasinette, Hans Wolfganf Singer and Evsey Domar can be cited among the intellectual economists from Oxport and London School of Economics that have contributed to developing post-Keynes economic models. (Romer, 1993)

In the model they formulized under the name of neo-classical growth, the economists such as Tobin, Swan and Solow alleged that labor and capital may substitute each other and thus they acted as inspiration for development of growth model by Harrod Domar and Singer. (Friedman, 1977).

The economists such as Paul Romer, Robert Barro and Robert Lukas developed endogenous growth model, putting forward that well-educated, experienced and skillful human capital of the nation, public property and infrastructural services owned by the nation, communication networks and internet providers would accelerate background information of both government and firms, contributing to encouragement of entrepreneurship and thus accelerating the economic growth. (McCallum, 1989). In this growth model, tax reduction and incentives provided by the government take important place.

That there were no Ottoman and, subsequently, Turkish economists to considerably contribute to the economics versus these developments occurred in the Western World is the most important indicator of our deficiency in this field.(Buyukakin and at all, 2010 and http://www.dunyabulteni.net_2010 Nobel ekonomi odulu). 67 economists have been awarded with NOBEL economics prize since 1969. Unfortunately, we see no economist of Turkish nationality among these scientists. Of NOBEL prizes, went to scientists who are citizen of USA (47), United Kingdom (8), Norway (3), Sweden (2), Israel, US-citizen at the same time (2), Holland (2), USSR (1), France (1), Germany (1), India (1), Canada (1) and South Cyprus, British citizen at the same time (1).

\section{ECONOMIC SCIENTISTS IN THE OTTOMAN STATE}

While revolutionary approaches and theories have appeared one after another upon industrialization in the Western World, the Ottoman Empire had to fight in a number of fronts to protect its territories and, therefore, gone into a decline in the fields of both agriculture and industry. As a result, no scientists came up to develop a serious approach and theory in the economic science. (http://eekonomist.net/wp-content/dosyalar/tis-iktisatcilar/html).

Roughly, there were no scientists in the Ottoman State to contribute to the economic science. Sehak Abru (Sehale) Efendi wrote a book in 1852 as a summary of the ideas of J.B.Say. Ahmet Mithat Efendi published a book titled "Political Economy" in 1879, consisting of a collection of articles, putting forward that the minorities supervised and plundered the Ottoman economy.

In 1881, Ohannes Efendi wrote an economic book, reflecting thoughts of Adam Smith as a textbook for the Faculty of Political Sciences. Portakal Mikail Paşa, together with Ohannes Efendi, put forward that industrialization was a waste of resources in their lectures at the Faculty of Political Sciences.(http://ekodialog.com/konular/iktisatcilar). Unfortunately, towards the end of $19^{\text {th }}$ century, Cavit Bey, following opinions of his teachers at the Faculty of Political Sciences, alleged that industrialization would impoverish the Ottoman State.

Akyiğitzade Musa, from Kazan Turks, taught at Faculty of Political Sciences. Although he supported ideas of Smith in his work IIIm-i Servet, he put forward that protectionism policy was required to protect infant industries as stated by the economist F. List. Per capita income was USD45 in the Ottoman State with its poorly operated agriculture-based economy, and this figure represented one fourth of the West European countries. Unfortunately, in the Ottoman State having an agricultural character, wheat was imported by payment of $\mathbf{1 2}$ million gold coins each year due to low agricultural productivity. (http://www.ekodialog.com/Konular/iktisatcilar). 
Banking and transportation sectors were also in the hands of the foreigners. And shares of Ottoman Bank, acting as Central Bank then, were also owned by the foreigners. When Mithat Paşa, a Turkish intellectual, established Ziraat Bank in 1868 and Istanbul Homeland Fund. He assigned Portakal Mikael Paşa, a minority having knowledge of banking, as the General Director of Ziraat Bank. It was very difficult to find an economic expert and conduct banking activities then.

\section{TURKISH ECONOMIC POLICY IN THE REPUBLIC ERA AND TURKISH ECONOMISTS CONTRIBUTING TO IT}

In the Republican era, Atatürk caused organization of Izmir Economic Congress in 1923, pointing out importance of the economy to the Turkish people. In this conference, the classical economic thoughts of Smith turned out to be dominant and it was considered that importance should be given to liberal economy and private entrepreneurship, supported by incentives. (Alkin,2010). However, Turkish people, lacking background of industry, entrepreneurship culture and experience on the one hand and having no sufficient capital accumulation, failed to make private ventures expected of them and thus, in 1931, the economic development policy gained important as a mixed economic development police where the private sector basing on the statist economic policies would make investments.

Ataturk welcomed the German economists fled from the prosecution in Nazi Germany, ensuring them to give lectures particularly in Istanbul University. These scientists have played important role in teaching the scientists to take office after them. Among them are particularly late Prof. Sabri ÜLGENER, our esteemed teacher, Prof.Dr.Ömer Lütfi BARKAN, Prof.Dr.Ömer Celal SARÇ, Prof.Dr.Sükrü BABAN, Prof.Dr.Hazim Atif KUYUCAK and Prof.Dr.Refii Sükrü SUVLA as valuable teachers of us, as well as the younger generation including Prof. Dr. Gülten KAZGAN, Prof. Dr.Mükerrem HIÇ, Prof.Dr.Ahmet KILIÇBAY, Prof.Dr.Feridun Ergin, Prof.Dr.Sadun AREN, Prof.Dr.Yüksel ÜLKEN, Prof.Dr.Aziz KÖKLÜ, Prof.Dr.Zeyyat HATIPOĞLU, Akin ILKIN, Idris KÜÇÜKÖMER and Sencer DIVITÇIOĞLU. There are about 50 professors that the teachers we mentioned above have taught, and most of them currently give lectures at a number of universities and colleges. These intellectual scientists shed light of the economic science to the Turkish students with books compiled from the world economic literature and articles. Especially Prof. Ülgener has considered that backwardness of our country was due to the esoteric, Sufi philosophy and life style, irrational and disconnected from Islam, making our people idle and lazy. (oakkusak@yenisafak.com.tr). In his work, Prof. Ülgener clearly described how an economi philosophy basing on Weberian rational thought and production may be established in an Islamic country. For this effort, our teacher is called Turkish Weber. (Sayar,2006).

Profesor Dr Zeyyat Hatipoglu, our valuable teacher, developed a special economic analysis, stating that he found out problems and remedies of Turkish economy. Prof Hatipodlu asserts that it is not accurate to calculate national income according to the purchasing power parity and the resulting figure to be obtained by this way would be misleading. According to him, the most important variable indicating national income level of a country is the energy consumption. Our teacher has stated that there are to productivity rates in practice, namely micro and macro, and that micro productivity means production of more commodity by use of less resource and lower number of people, but macro productivity, meaning efficiency of the economy as a whole, is very low, adding that Turkey has grown by $4 \$$ in average for 80 years, employing higher number of people. He also put forward that while $12 \mathrm{~m}$ people were employed in the early years of the Republic, today $22 \mathrm{~m}$ people are employed; on the other hand, while $11-12 \%$ of the national income was assigned to investment formerly, we now reserve $22-23 \%$ of it for investment; as a result, increase of annual input for production is about $3.5 \%$ in average, but the increase of national income stemming from this increased productivity is only at $0.5 \%$, remaining very low compared to the global criteria. (Hatipoglu, 1995 and 1978).

We hope young generations hold up Mr. Hatipoglu as an example, being an intellectual scientist who wrote a number of books and articles in English in the field of economy and business management.

Our young economic scientists write scientific studies and articles in English in the prestigious publications worldwide. Number of these intellectuals has already reached to $\mathbf{7 1 0}$. (http://www.eeconomist.net/turkiye iktisatcilar siralamasi/) Furthermore, there are 9 young Turkish intellectuals attended at the mostly read Turkish Economists who currently work at Harvard University, USA, World Bank, MIT, Ankara University and IMF and some other American Universities and publish their articles in the world-known journals. We hope that these promising young people would make studies to be awarded with NOBEL economic prize. 


\section{TURKISH ECONOMISTS WHO MADE A NAME FOR THEMSELVES IN THE ECONOMIC LITERATURE TODAY}

We have seen above that there were not economists in the Ottoman State to review developments in the field of economy worldwide, converting them to state policies and, surprisingly, the existing few number of economists could not grasp role and important of the industrialization in the economic development, considering it as something to be avoided. Today there are Turkish economists that are known by all economic circles worldwide, working in the prestigious and leading foreign and local universities, writing articles as world-class scientists and economists.

The following Table 1 shows Turkish economics with their articles published in the journals listed by SSCI, ordered in accordance with impact score. And the Table 2 indicates our valuable economists

\begin{tabular}{|c|c|c|c|}
\hline \multicolumn{4}{|c|}{$\begin{array}{l}\text { Table-1 Turkish Economists Mostly Read Worldwide (source: prepared by benefiting from the } \\
\text { website http://wWw.e-ekonomist.net/wp-content/dosyalar/tis-iktisatcilar.html supported by } \\
\text { additional information.) }\end{array}$} \\
\hline Identity & $\begin{array}{l}\text { Total Number of Readings and Range of } \\
\underline{\text { Study }}\end{array}$ & $\begin{array}{l}\text { World } \\
\text { Ranking }\end{array}$ & Currently Working At \\
\hline $\begin{array}{l}\text { Dani RODRIK } \\
\text { 1957, graduated from Robert College, } \\
\text { MPA in Harvard University, Ph.D in } \\
\text { Princeton University. Leontief Prize in } \\
2002 .\end{array}$ & $\begin{array}{l}\text { Read } 22.974 \text { times. } \\
\text { Range of Study: Globalization, Interna- } \\
\text { tional economy, economic development and } \\
\text { growth }\end{array}$ & 25 & $\begin{array}{l}\text { Teaching International Political } \\
\text { Economy in Kennedy School of } \\
\text { Government, Harvard University, } \\
\text { USA }\end{array}$ \\
\hline $\begin{array}{l}\text { Aslý Demirgüc-Kunt } \\
\text { Graduated from Economics Department, } \\
\text { Bosphorus University, MA. and Ph. D in } \\
\text { Ohio State University; started to work at } \\
\text { World Bank in } 1989 .\end{array}$ & $\begin{array}{l}\text { Read 20.414 times. } \\
\text { Range of Study: Financial Economy and } \\
\text { Problems and Remedies of Finance sector; } \\
\text { published more than } 100 \text { academic journals. }\end{array}$ & 34 & $\begin{array}{l}\text { Chief Economist, Financial and } \\
\text { Private Sector and Senior Research } \\
\text { Manager, World Bank }\end{array}$ \\
\hline $\begin{array}{l}\text { Daron ACEMOGLU } \\
\text { 1967, Istanbul; Galatasaray High School; } \\
\text { BA. and MA. in York University, UK. Ph. } \\
\text { D. in London School of Economics. }\end{array}$ & $\begin{array}{l}\text { Read 17.221 times. } \\
\text { Range of Study: } \\
\text { Political Economy; economic development } \\
\text { and growth; income and wage inequality; } \\
\text { John Bates Clark prize and medal in } 2005 \text {. } \\
\text { Ranked } 8^{\text {th }} \text { best economist worldwide in his } \\
\text { field. }\end{array}$ & 53 & $\begin{array}{l}\text { Teaches in Massachusetts Institute of } \\
\text { Technology since 1993. Became } \\
\text { Professor in } 2000 .\end{array}$ \\
\hline $\begin{array}{l}\text { Aykut KIRBITCIOGLU } \\
\text { 1962, Istanbul; BA. and MA. in Political } \\
\text { Sciences Faculty; Ph. D. in Kiel Univer- } \\
\text { sity, Germany. }\end{array}$ & $\begin{array}{l}\text { Read } 14.033 \text { times. } \\
\text { Range of Study: } \\
\text { International Economics, International } \\
\text { Economics Relations, Economic Growth, } \\
\text { Macro Economics Policy, Turkey-EU } \\
\text { Customs Union and Economic Policy }\end{array}$ & 80 & $\begin{array}{l}\text { Lecturer in Economics Department, } \\
\text { Faculty of Political Sciences, Ankara } \\
\text { University. }\end{array}$ \\
\hline $\begin{array}{l}\text { Jess BENHABIB } \\
\text { 1948; Ph. D. in Columbia University in } \\
\text { 1976, USA. Lecturer in Southern Califor- } \\
\text { nia University since } 1977 .\end{array}$ & $\begin{array}{l}\text { Read 7.221 times. } \\
\text { Range of Study: } \\
\text { Political Economy, economic growth, } \\
\text { monetary policy, econometric models. } \\
\text { Associate editor of five economic journals. }\end{array}$ & 268 & $\begin{array}{l}\text { Started to work in New York Univer- } \\
\text { sity in } 1984, \text { still teaching in the } \\
\text { same university. }\end{array}$ \\
\hline $\begin{array}{l}\text { Mustafa CAGLAYAN } \\
\text { 1965, BA. in the Department of Electric } \\
\text { Engineering, Bosphorus University in } \\
\text { 1987; completed his MA. in Economics, } \\
\text { Bosphorus University. Ph. D. in economics } \\
\text { in Boston College, USA, 1997. Became } \\
\text { Professor in Glasgow University, UK, } \\
2005 \text {. }\end{array}$ & $\begin{array}{l}\text { Read } 6.799 \text { times. } \\
\text { Range of Study: } \\
\text { Articles in the monetary and banking fields } \\
\text { of macro economics as well as international } \\
\text { economics and applied economics. }\end{array}$ & 301 & $\begin{array}{l}\text { Working as Professor in Sheffield } \\
\text { University, United Kingdom, since } \\
2006 .\end{array}$ \\
\hline $\begin{array}{l}\text { Selahattin DIBOGLU } \\
\text { BA. in Economics, Gazi University. Ph.D } \\
\text { in Economics, Political Sciences Faculty, } \\
\text { Ankara University. Ph.D. in Economics, } \\
\text { Iowa University, USA. }\end{array}$ & $\begin{array}{l}\text { Read } 5109 \text { times. } \\
\text { Range of Study: } \\
\text { Development economics; European Eco- } \\
\text { nomics; Post-Keynes economies; Technol- } \\
\text { ogy and Industry Dynamic }\end{array}$ & 472 & $\begin{array}{l}\text { Working as Economics Professor in } \\
\text { Missouri University, Saint Louis, } \\
\text { USA. }\end{array}$ \\
\hline $\begin{array}{l}\text { Metin COSGEL } \\
1960 ; \text { BA. in Economics, Bosphorus } \\
\text { University in 1983. MA. and Ph. D. in } \\
\text { Iowa University, USA. Associate Profes- } \\
\text { sor in Economics, 1989. }\end{array}$ & $\begin{array}{l}\text { Read } 3894 \text { times. } \\
\text { Range of Study: } \\
\text { Studies and articles on Middle East Eco- } \\
\text { nomics History, Economic thought history. }\end{array}$ & 693 & $\begin{array}{l}\text { Working in Connecticut University, } \\
\text { USA since 1989. Guest lecturer in } \\
\text { Harvard and Yale Universities. }\end{array}$ \\
\hline $\begin{array}{l}\text { Ayhan KÖSE } \\
1956 ; \text { MA., Industrial Engineering Depart- } \\
\text { ment, Bilkent University in 1992. Ph.D. in } \\
\text { Business Economics, Iowa University, } \\
1997 .\end{array}$ & $\begin{array}{l}\text { Read } 3409 \text { times. } \\
\text { Range of Study: } \\
\text { Studies and articles on globalization in } \\
\text { terms of finance in economic dynamics, } \\
\text { macro financial connections between the } \\
\text { countries in USA, Canada and Western } \\
\text { Hemisphere. }\end{array}$ & 821 & $\begin{array}{l}\text { Senior economist and assistant } \\
\text { manager, Research Department, } \\
\text { International Monetary Funds. Editor } \\
\text { of the journal Economy published by } \\
\text { IMF; giving lectures as guest lecturer } \\
\text { in a number of universities. }\end{array}$ \\
\hline
\end{tabular}


ranked in accordance with the mostly-read works worldwide. It appears that number of these valuable scientists will increase every day, guiding the world economy and working in the prestigious universities in USA. (http://www.e-ekonomist.net/turkiye-iktisatcilar-siralamasi) Development thrusts in our economy have gained acceleration in all industrial and service sectors. We believe that in parallel with the economic developments number of Turkish economists and their works worldwide will certainly increase.

\begin{tabular}{|c|c|c|}
\hline Full Name & Working for & $\begin{array}{l}\text { Ranking by SSCI Impact } \\
\text { Score }\end{array}$ \\
\hline $\begin{array}{l}\text { Tayfun } \\
\text { SÖNMEZ }\end{array}$ & $\begin{array}{l}\text { Koç University } \\
\text { Range of Study: Market Design, Game Theory, Social } \\
\text { Choice Theory }\end{array}$ & 7,0125 \\
\hline Mehmet BAÇ & $\begin{array}{l}\text { Sabanci University } \\
\text { Range of Study : Microeconomy, Industrial Organiza- } \\
\text { tions, Effects on Law and Economics }\end{array}$ & 5,354 \\
\hline Murat USMAN & $\begin{array}{l}\text { Koç University } \\
\text { Range of Study : Microeconomics, Industrial Organiza- } \\
\text { tions, Applied Game Theory, Contract Approaches in } \\
\text { Economics }\end{array}$ & 3,163833333 \\
\hline Utku ÜNVER & $\begin{array}{l}\text { Koç University } \\
\text { Range of Study : Microeconomics, Market Design, Ex- } \\
\text { perimental and Numerical Economics, Game Theory }\end{array}$ & 2,76766667 \\
\hline $\begin{array}{l}\text { Hakan BERU- } \\
\text { MENT }\end{array}$ & $\begin{array}{l}\text { Bilkent University } \\
\text { Range of Study: Macroeconomics, Monetary Policy, } \\
\text { Exchange Rates, Price Indices, Econometry }\end{array}$ & 2,485333333 \\
\hline Osman ZAIM & $\begin{array}{l}\text { Kadir Has University } \\
\text { Range of Study : Microeconomics, Econometry, Envi- } \\
\text { ronmental Economics, Public Finance }\end{array}$ & 2,3485 \\
\hline Semih KORAY & $\begin{array}{l}\text { Bilkent University } \\
\text { Range of Study: Market and Social Designs, Game } \\
\text { Theory, Mathematical Economics }\end{array}$ & 2,3315 \\
\hline $\begin{array}{l}\text { Kamil YIL- } \\
\text { MAZ }\end{array}$ & $\begin{array}{l}\text { Koç University } \\
\text { Range of Study: Macroeconomics, International Fi- } \\
\text { nance, Global Economic Crises, International Trade, } \\
\text { Turkish Economy }\end{array}$ & 2,327 \\
\hline Özgür KIBRIS & $\begin{array}{l}\text { Sabanci University } \\
\text { Range of Study: Microeconomics, Game and Bargain- } \\
\text { ing Theory, Design Economics }\end{array}$ & 2,196 \\
\hline $\begin{array}{l}\text { Korkut } \\
\text { BORATAV }\end{array}$ & $\begin{array}{l}\text { Ankara University (Retired Professor) } \\
\text { Range of Study : International Economics, Develop- } \\
\text { ment Economics and Policy, Turkish Economy }\end{array}$ & 2,115 \\
\hline
\end{tabular}




\section{V-CONCLUSION}

In this article, we briefly dealt with the intellectuals contributed to the science of economics and mentioned about the economic policies formed by their ideas. First of all, we may say that the prophets, as religious leaders, have established a lifestyle and moral sentiment through inclusion of the economic rules and rudiments in the religious values.

And the Ancient Greek philosophers also formulated important rules, still maintaining their validity today. The first studies in the field of agricultural economy date back to the ancient Rome. And the matter of prevention of the inequality in income distribution goes back to Marcus Aurelius we took measures against it.

In the Middle Ages, the Western World went into a completely dark period. Strict rules of the Christianity caused an infertile era in the field of economics. In the Ottoman State, Sheik Badraldin, as the first socialist and utopist thinker, has taken his place in the world of economics.

However, upon start of Renaissance and religious reform area in the New Age, we see appearance of protectionism and liberal economic ideas and, with effect of mercantilist approaches, causing start of colonialism in Europe. Physiocrats, advocates of natural order and representative of the nobles acting as feudal landowners, drew attention to the agriculture, defending agricultural production. However, basing upon the idea of strong states having control upon the economy, utopists drew attention to the industrial society. Thus, seeds of liberal economic thoughts were planted. Adam Smith was deeply affected by the mercantilism and ideal state order of the utopist writers.

And economic policies appeared in favor of the proletariat class that were suppressed and exploited by the liberal economic thought. Finally, we see scientific socialism or communism, Proletariat Empire, as the advanced stage of the socialism as formulized by Karl Marx. Later on, other economic policies have appeared against the economic approach of Marx, which soften wrong applications of the liberal thought, finding ways to improvement for the workers class by measures of intervention and precautions to prevent excess competition conflicts of the firms. Even in Germany, we see policies to intervene with fresh and infant industrial organizations.

In 1929 economic crisis brought end of the liberal economic policies. Neoclassical economic policies were formed, putting forward in which conditions the state should intervene with the economy. Later on, neoclassical growth models and endogenous growth model, more advanced form of the former, appeared as tools guiding for economic development plans and strategies.

While these developments have occurred in the Western world, there were no well-educated people in the Ottoman State and, subsequently in the early years of the Republic of Turkey established in 1923. Even today, we have no Turkish Economist awarded with Nobel Economics Prize since 1969. The lecturer teaching at the Faculty of Political Sciences and Military College in the Ottoman State were so far away from the science and technology so as to put forward that industrialization would be a waste of resources. There were even scientists defending that Turkish people are not required to deal with industry and trade as it was in the hands of the foreigners,

In the Republican era, M.K.Ataturk, forefather of modern Turkish state, convened Izmir Economics Congress with an effort to develop plans and policies for initiatives to be performed in the agricultural and industrial fields in Turkey. As this plan, basing on liberal economy and entrepreneurship, did not give result in short time, we see appearance of the statist policies from 1931 on that require the state enters into economy, making investments. However, private entrepreneurship has not been hindered, thus systems and strategies of the mixed economy were kept in practice.

Refugees from Europe to Turkey during the World War II had important roles and contributions in bringing up Turkish scientists in the field of economics. Today, our economists brought up in Turkey and completed their study abroad made important studies worldwide and managed to appear in the list of intellectuals, mostly-read and with high SSCI impact scores. 


\section{REFERENCES}

Alkin, Erdoğan, Kurumlarla Yakın Ekonomi Tarihi, Ýstanbul Ticaret Odası Yayını No: 2010-55

Büyükakın, Tahir, Yapar Bülbül, Necip Çakır, Nobel'in izinde İktisat Kuramının Gelişimi, İstanbul Ticaret Odası Yayını No: 2010-50

Hiç, Mükerrem, Türkiye Ekonomisi, İstanbul Üniversitesi İktisat Fakültesi Yayını, İstanbul 1983. Sayar, Ahmed Güner, Ülgener Yazıları, Derin Yayınları, İstanbul 2006.

oakkusak@yenisafak.com.tr (Mütefekkir bir İktisatçı Sabri ÜLGENER)

http://www.ekodialog.com/Konular/İktisatçılar/;

Parasız, İlker, İktisadın A, B, C'si, Gözden Geçirilmiş ve Genişletilmiş 11. Baskı, Ezgi Kitabevi, Bursa 2010.

Parasız, Illker; Makro Ekonomi, Teori ve Politika, Ezgi Kitabevi Yayınları, 9.Baskı, Bursa, 2006.

Dornbush, Rudiger ve Stanley Fisher; Macroeconomics, Mc Graw Hill, New York, 1990.

Gordon, J.Robert; Microeconomics, 10.th edition Addison Wesley, Now York 2006.

Lavoie M. Macroeconomie: Theorie et Controverses Post-Keynesiennes, Dunod, Paris, 1987.

Mc Callum, Bennette; Monotary Economics, Theory and Policy, Macmillan, New York, 1989.

Parkin, Michael, Economics 7. edition, Addison Wesley Publishing Company, New York 2005.

Romer, David; New Keynesian Synthesis, Journal of Economic Perspectives, vol:7, No:1 Year 1993.

Ülgener, Sabri Fehmi; Para, İstihdam ve İktisadi Büyüme, İstanbul Üniversitesi İktisat Fakültesi Yayınları, İstanbul 1962.

www.nedir.antoloji.com/seyh.bedrettin/

http://www.e-konomist.net/türkiye-iktisatcilar-sıralamasl/

http://www.e-ekonomist.net/wp-content/dosyalar/tis-iktisatcilar.html

http://www.dunyabulteni.net/?aType-haber\&Article ID-132393 (Dünya Bülteni/Genel) 2010 Nobel Ekonomi Ödülï

Vikipedi, Özgür Ansiklopedi

www.gulsunyay.com (Prof.Dr.Gülsün YAY kipisel web sitesi: Yeni Klasik Makroiktisat)

Friedman, Milton; "Nobel Lecture: Inflation and Unemployment”, Journal of Political Economy, 85 (3) 1977.

Phelps; E.S.; Seven Schools of Macroeconomics Thought, Clerendon Press, 1990.

Hatipoğlu, Zeyyat; Economic Theory and Turkish Experience, Literatür Yayıncılık, 1995.

Hatipoğlu, Zeyyat; An Unconventional Analysis of the Turkish Economy: an Essay on Economic Development, Istanbul 1978. 